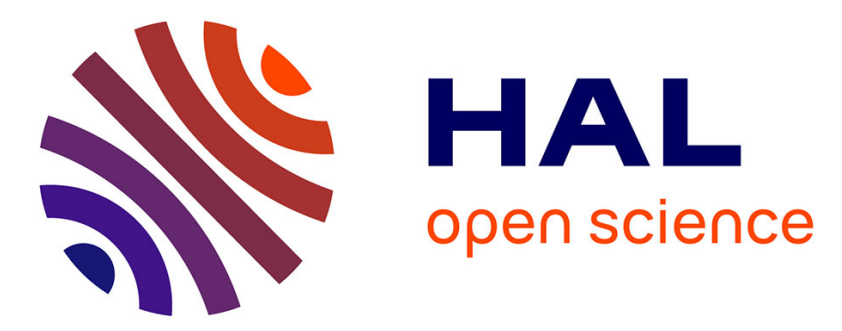

\title{
High pressure intrusion-extrusion of electrolyte solutions in aluminosilicate FAU and *BEA-type zeolites
}

\author{
A. Ryzhikov, I. Khay, H. Nouali, T.J. Daou, J. Patarin
}

\section{To cite this version:}

A. Ryzhikov, I. Khay, H. Nouali, T.J. Daou, J. Patarin. High pressure intrusion-extrusion of electrolyte solutions in aluminosilicate FAU and *BEA-type zeolites. Microporous and Mesoporous Materials, 2016, 221, pp.1-7. 10.1016/j.micromeso.2015.08.040 . hal-03543869

\section{HAL Id: hal-03543869 \\ https://hal.science/hal-03543869}

Submitted on 26 Jan 2022

HAL is a multi-disciplinary open access archive for the deposit and dissemination of scientific research documents, whether they are published or not. The documents may come from teaching and research institutions in France or abroad, or from public or private research centers.
L'archive ouverte pluridisciplinaire HAL, est destinée au dépôt et à la diffusion de documents scientifiques de niveau recherche, publiés ou non, émanant des établissements d'enseignement et de recherche français ou étrangers, des laboratoires publics ou privés. 


\title{
High pressure intrusion-extrusion of electrolyte solutions in aluminosilicate FAU and *BEA-type zeolites
}

\author{
A. Ryzhikov*, I. Khay, H. Nouali, T.J. Daou, J. Patarin **
}

Université de Haute Alsace (UHA), CNRS, Equipe Matériaux à Porosité Contrôlée (MPC), Institut de Science des Matériaux de Mulhouse (IS工M), UMR 7361, ENSCMu, 3 bis rue Alfred Werner, F-68093 Mulhouse, France

A B S T R A C T

The energetic performances of several FAU- and "BEA-type zeolites with different Si/Al molar ratios have been studied by high pressure intrusion-extrusion of water and $\mathrm{LiCl}$ aqueous solutions. It has been shown that FAU-type zeolites characterized by a low $\mathrm{Si} / \mathrm{Al}$ molar ratio (up to 40 ) demonstrate hydrophilic properties and spontaneous intrusion of water and LiCl solutions. While dealuminated Y zeolite (DaY) with a Si/Al ratio of 110 displayed a shock-absorber behavior under intrusion of $\mathrm{LiCl}$ solutions with concentration ranging from 5 to $20 \mathrm{M}$; however the intrusion of water was spontaneous. The increase of the $\mathrm{LiCl}$ concentration leads to an increase of both the intrusion pressure and the intruded volume, but also a better efficiency of the shock-absorber. "BEA-type zeolite with a Si/Al ratio of 90 displayed a spring behavior under intrusion of $20 \mathrm{M} \mathrm{LiCl}$ solution with an intrusion pressure of $59 \mathrm{MPa}$ and an intruded volume of $0.09 \mathrm{~mL} / \mathrm{g}$, whereas the intrusion of solutions with lower concentration was spontaneous. It has been shown that only zeolites with high $\mathrm{Si} / \mathrm{Al}$ ratios can demonstrate high pressure intrusion of electrolyte solutions and that the presence of small traces of aluminum atoms changes considerably the behavior of the "zeolite-liquid" system. The characterization of the samples, before and after intrusion -extrusion experiments, by various physicochemical and structural methods has been performed.

\section{Introduction}

Zeolites are widely used for various applications in adsorption, separation, ion-exchange and heterogeneous catalysis [1]. In the past decade, thermodynamics of confined systems involving water as nonwetting liquid and hydrophobic microporous solids as allsilica zeolites (zeosils) have attracted considerable attention due to their potential application in the field of energetics. Since our pioneering work in 2001 [2], several "zeosil-water" systems have already been studied [3-19] and a summary of the energetic performances of these all silica zeolites was reported in our previous paper [19]. The use of "zeosil-water" system in energetic applications is based on the following principle. To penetrate water in the porous solid (intrusion), a certain pressure must be applied. Under intrusion liquid water is transformed into a multitude of molecular clusters in the pores. Thus, the supplied mechanical energy during the compression step is converted to interfacial energy. By reducing

\footnotetext{
* Corresponding author

*. Corresponding author.
}

the pressure, the system can induce an expulsion of the liquid out of the pores of the solid (extrusion). Depending on the zeosil, the "zeosil-water" system is able to restore, dissipate, or absorb energy and therefore, it displays a spring, shock-absorber, or bumper behavior, respectively. The behavior depends on various physical parameters related to the porous matrix such as pore size, pore system (cages or channels), dimensionality of the channels and the hydrophobic/hydrophilic character of the solids. This latter parameter depends on the number of defect sites in the zeolite material. Thus, the presence of silanol groups can considerably change the behavior of the "zeosil-water" system as it was observed for MFI-type zeolites [2]. It is well known that aluminosilicate zeolites demonstrate generally hydrophilic properties. However, at high $\mathrm{Si} / \mathrm{Al}$ molar ratio their hydrophobic character increases. The intrusion-extrusion of different electrolyte solutions in hydrophobic porous solids can be a way to improve their energetic performances $[20,21]$. It has been found that highly concentrated aqueous solutions of salts such as $\mathrm{LiCl}, \mathrm{NaC}, \mathrm{MgCl}_{2}$ enhance the intrusion pressure up to 3 times (in the case of the "Silicalite-1$\mathrm{LiCl} 20 \mathrm{M}$ " system) and that the pressure increases along with the salt concentration $[20,22]$. In the works of Qiao and coworkers, FAU 
and MFI-type aluminosilicate zeolites with high $\mathrm{Si} / \mathrm{Al}$ ratio have been studied under intrusion-extrusion of water and electrolyte solutions $[21,23]$. FAU-type zeolite with $\mathrm{Si} / \mathrm{Al}$ ratio of 40 demonstrated a shock-absorber behavior under intrusion of $\mathrm{NaCl}, \mathrm{NaBr}$ and $\mathrm{KCl}$ solutions, the higher the electrolyte concentration, the higher the intrusion pressure. Whereas, once this FAU-type sample is immersed in water, the latter is soaked up spontaneously [23-25]. However no characterizations were performed on the solids after the intrusion experiments. Recently, new effect was observed in the case of "BEA-type zeosil: the intrusion of highly concentrated LiC solutions change drastically the system behavior - from bumper, with an irreversible intrusion of liquid (water and $\mathrm{LiCl}$ solutions up to $10 \mathrm{M}$ ), to shock-adsorber (with $\mathrm{LiCl}$ solution $>15 \mathrm{M}$ ). The change of the system behavior was explained by a change in the nature of the intruded liquid - from water to highly concentrated $\mathrm{LiCl}$ solution with $\mathrm{H}_{2} \mathrm{O} / \mathrm{Li}^{+}$molar ratio lower than $\mathrm{Li}^{+}$coordination number [26]. That is why the intrusion of such highly concentrated solutions presents a particular interest. It should be noted that the solutions with very small $\mathrm{H}_{2} \mathrm{O} /$ cation ratio were previously studied only in few works $[20,22,26]$.

In this article the intrusion-extrusion experiments of water and highly concentrated LiCl solutions in FAU and "BEA-type zeolites with different $\mathrm{Si} / \mathrm{Al}$ molar ratios were performed in order to study the influence of $\mathrm{Si} / \mathrm{Al}$ ratio on intrusion-extrusion behavior of "zeolite - non-wetting liquid" system. The solids were fully characterized before and after intrusion-extrusion experiments by Xray diffraction, $\mathrm{N}_{2}$ adsorption desorption measurement, Scanning Electron Microscopy (SEM), TG analyses and solid state NMR spectroscopy. The influence of the electrolyte concentration on the energetic performances of the "zeolite-electrolyte" system is also discussed in order to demonstrate particular properties of highly concentrated electrolyte solutions.

\section{Experimental}

The following commercial and laboratory-made FAU and 'BEAtype zeolite samples with various $\mathrm{Si} / \mathrm{Al}$ ratios were studied: FAUtype zeolite - NaX (Sigma Aldrich, Si/Al = 1.3), EMC-1 (home made, $\mathrm{Si} / \mathrm{Al}=3.8)[27]$, dealuminated HY zeolites (Zeolyst CBV720, $\mathrm{Si} / \mathrm{Al}=15, \mathrm{CBV} 780, \mathrm{Si} / \mathrm{Al}=40$ ) and $\mathrm{DaY}$ zeolite (Degussa $\mathrm{Si} /$ $\mathrm{Al}=110)$, "BEA-type zeolite - Zeolyst CBV $811 \mathrm{C}(\mathrm{Si} / \mathrm{Al}=150)$ and Clariant H-BEA-150 ( $\mathrm{Si} / \mathrm{Al}=90)$.

The Si/Al molar ratio of the different samples was determined by $\mathrm{X}$-ray Fuorescence spectrometry on a Philips PW spectrometer.

Intrusion-extrusion experiments of aqueous solutions in the zeolite sample in the form of compressed and preliminary degassed (at $300{ }^{\circ} \mathrm{C}$ under vacuum) pellets were performed at room temperature using a modified mercury porosimeter (Micromeritics Model Autopore IV), as described in our previous works [19]. The liquid phase was either pure water or aqueous solution of lithium chloride with various concentrations $(5,10,15$ or $20 \mathrm{M}$ ). The compressibility curve of pure water or Lid aqueous solution was subtracted from experimental intrusion-extrusion curves. The values of the intrusion $\left(\mathrm{P}_{\mathrm{int}}\right)$ and extrusion $\left(\mathrm{P}_{\text {ext }}\right)$ pressures correspond to that of the half volume total variation. The pressure is expressed in megapascals (MPa) and the volume variation in milliliters ( $\mathrm{mL}$ ) per gram of calcined samples. The experimental error is estimated to $1 \%$ on the pressure and on the volume.

After intrusion-extrusion experiments, the samples intruded with $\mathrm{LiCl}$ were washed with water to remove traces of $\mathrm{LiCl}$. The absence of chloride anions in the filtrate was controlled by adding few drops of $1 \mathrm{M}$ silver nitrate aqueous solution (no silver chloride precipitate). Then the samples were dried at $70^{\circ} \mathrm{C}$ overnight, and hydrated in a $80 \%$ relative humidity atmosphere during $24 \mathrm{~h}$.
X-ray powder diffraction patterns of the different samples were recorded in a Debye-Scherrer geometry on a STOE STADI-P diffractometer equipped with a curved germanium (111) primary monochromator, and a linear position-sensitive detector $\left(6^{\circ} 2 \theta\right)$ using $\mathrm{Cu} K \alpha_{1}$ radiation $(\lambda=0.15406 \mathrm{~nm})$. Measurements were achieved for $2 \theta$ angle values in the $3-50$ range, step $0.15^{\circ} 2 \theta$, and time/step $=120 \mathrm{~s}$. The unit-cell parameters were determined using Louerr's DICVOL91 indexing routine [28] of the STOE WinXPOW program package [29].

The size and the morphology of the crystals were determined by Scanning Electron Microscopy (SEM) using a Philips XL 30 FEG microscope.

Nitrogen adsorption-desorption isotherms were performed at $-196^{\circ} \mathrm{C}$ using a Micromeritics ASAP 2420 apparatus. Prior to the adsorption measurements, the samples were outgassed at $90{ }^{\circ} \mathrm{C}$ overnight under vacuum to eliminate physisorbed water. Low degassing temperature was chosen to avoid the dehydroxylation process. The specific surface area (SBET) and microporous volume ( $\left.V_{\text {micro }}\right)$ were calculated using the BET and t-plot methods, respectively,

Thermogravimetric (TG) analyses were carried out on a TG Mettler Toledo STARe apparatus, under air flow, with a heating rate of $5^{\circ} \mathrm{C} / \mathrm{min}$ from 30 to $800^{\circ} \mathrm{C}$. As mentioned above, all samples were hydrated in $80 \%$ relative hum idity atmosphere during $24 \mathrm{~h}$ in order to set the hydration state.

${ }^{29} \mathrm{Si}$ MAS and ${ }^{1} \mathrm{H}-{ }^{29} \mathrm{Si}$ CPMAS NMR spectra were recorded on a Bruker Advance II $300 \mathrm{MHz}$ spectrometer, with a double-channel $7 \mathrm{~mm}$ Bruker MAS probe. The recording conditions are given in Table 1.

\section{Results and discussion}

\subsection{Intrusion-extrusion isotherms}

Firstly the experiments of intrusion of water and the most concentrated $\mathrm{LiCl}$ solution $(20 \mathrm{M})$ were performed for all the samples. It was observed that almost all the faujasite zeolites ( $\mathrm{Si} / \mathrm{Al}$ ratio: 1,$3 ; 3,8 ; 15 ; 40$ ) demonstrate hydrophilic properties: the intrusion of $\mathrm{H}_{2} \mathrm{O}$ and $20 \mathrm{M} \mathrm{LiCl}$ solution takes place spontaneously (the samples soak up the liquid at atmospheric pressure). Only DaY zeolite, with the highest $\mathrm{Si} / \mathrm{Al}$ molar ratio (110) among all the FAUtype zeolites showed a shock-absorber behavior under intrusion of $20 \mathrm{M} \mathrm{LiCl}$ (Fig. 1), whereas the intrusion of water was spontaneous as observed for the other studied faujasite zeolites. Hydrophilic properties of faujasite zeolites with low Si/Al ratio $(\leq 15)$ are not surprising since the adsorption of water and other polar molecules are well known for these materials. However, it was quite surprising that the commercial desaluminated $\mathrm{Y}$ zeolite with a $\mathrm{Si} / \mathrm{Al}$ ratio of 40 (CBV 780) demonstrates spontaneous intrusion of water

Table 1

Recording Conditions of the ${ }^{20}$ Si MAS and ${ }^{1} \mathrm{H}-{ }^{20}$ Si CPMAS NMR Spectra.

\begin{tabular}{lll}
\hline & & \\
\cline { 2 - 3 } & MAS & CP MAS \\
\hline Chemical shift standard & TMS & TMS $^{4}$ \\
Frequency $(\mathrm{MHz})$ & 59.6 & 59.6 \\
Pulse width $(\mu \mathrm{s})$ & 1.87 & 4 \\
Flip angle & $\pi / 6$ & $\pi / 2$ \\
Contact time $(\mathrm{ms})$ & - & 8 \\
Recycle time $(\mathrm{s})$ & 80 & $10^{\circ}$ \\
Spinning rate $(\mathrm{kHz})$ & 4 & 4 \\
Scans number & 1000 & 8000 \\
\hline
\end{tabular}

4 TMS: TetraMethylSilane

b The relaxation time $\mathrm{t}_{1}$ was optimized. 


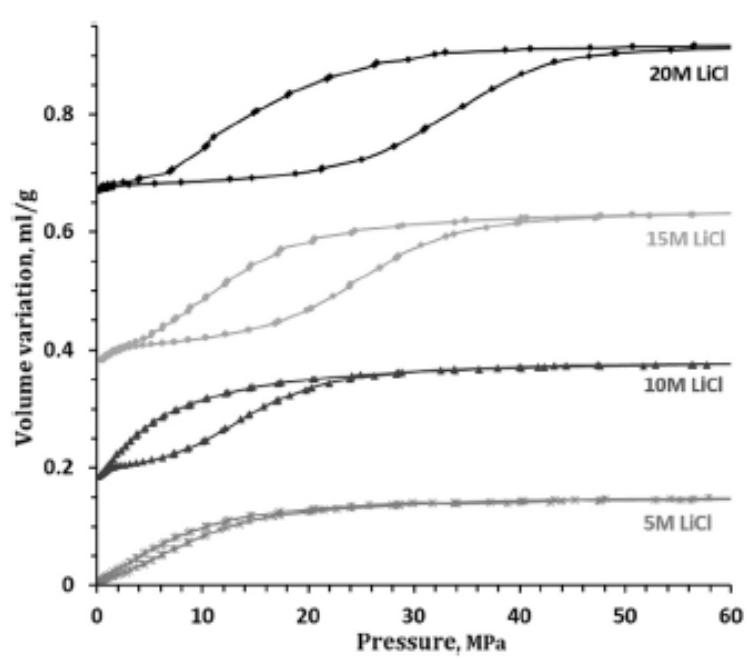

Fig 1. The first intrusion -extrusion cycle of the "DaY-LiCl aqueous solution" systems. For a better visibility, the diagrams are shifted along the $\mathrm{Y}$-axis.

and $20 \mathrm{M} \mathrm{LiCl}$ solution. Indeed, in the works of Qiao and coworkers, the faujasite CBV901 from Zeolyst $(\mathrm{Si} / \mathrm{Al}$ ratio $=40)$ displayed a shock-absorber behavior under intrusion-extrusion of concentrated $\mathrm{NaCl}, \mathrm{NaCl}+\mathrm{NaBr}$ and $\mathrm{KCl}$ solutions with an intrusion pressure up to $20 \mathrm{MPa}$ [23-25]. It can be supposed that the number of hydrophilic defect sites (silanol sites, since both zeolites are in protonated form) is higher in the CBV 780 faujasite sample compared to the CBV901 one.

In order to study the influence of the electrolyte concentration on the energetic performances of DaY zeolite, intrusion/extrusion experiments were also performed with 5,10 and $15 \mathrm{M} \mathrm{LiCl}$ solutions. For each system, three intrusion-extrusion cycles were performed and reproducible results were obtained. Since the cycles are extremely close one to another, for clarity, only the first intrusion-extrusion cycles are reported for each experiment. The corresponding intrusion-extrusion curves are shown in Fig. 1. In the case of $20 \mathrm{M} \mathrm{Lidl}$ solution the systems demonstrate a shockabsorber behavior. The energetic performances of system are summarized in Table 2. It is observed that the intrusion and extrusion pressures increase considerably with the Lid concentration. The obtained intruded volume when using 15 and $20 \mathrm{M} \mathrm{LiCl}$ solution was about $0.23 \mathrm{~mL} / \mathrm{g}$ which corresponds to the one obtained by Qiao and coworkers while using other electrolyte solutions [25]. However, this volume is lower than the one determined from $\mathrm{N}_{2}$ adsorption-desorption ex periment $(0.28 \mathrm{~mL} / \mathrm{g})$. As already mentioned by Desbiens et al. [5], for the "Silicalite-1 water" system such a difference can be due to a density of the intruded liquid lower than that of the bulk liquid. At lower concentrations, for instance for the $5 \mathrm{M} \mathrm{LiCl}$ solution, the intruded volume decreases

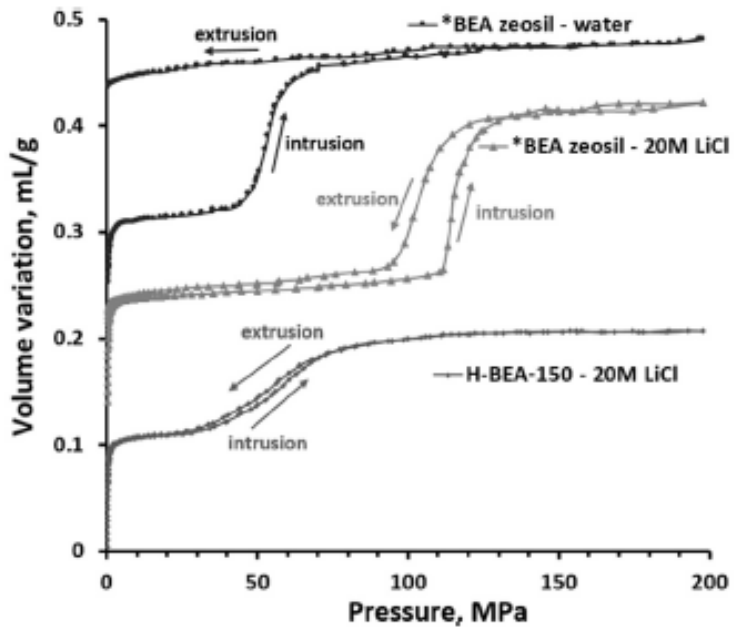

Fi. 2. Intrusion-extrusion cycle of the "H-BEA-150-20 M LiC" system. For comparison, the "pure-silica"BEA zeolite - water" and "pure-silica"BEA zeolite - $20 \mathrm{M} \mathrm{LiCr}$ systems adapted from Ref. [26] are also reported.

up to $0.13 \mathrm{~mL} / \mathrm{g}$ with an energy yield (restored energy to absorbed energy ratio) of $71 \%$ At this low concentration, the solution or free water molecules (nonsolvated molecules) spontaneously fill in the most hydrophilic parts of the pores. Similar energy yields (48-51\%) were observed for higher concentrations of Lid solutions (10, 15 and $20 \mathrm{M}$ ). Such yields are expected for a shock-absorber.

For the "BEA-type zeolites, the two commercial samples (CBV $811 \mathrm{C}$ and H-BEA-150) show hydrophilic properties with spontaneous intrusion of water and $\mathrm{LiCl}$ solutions in the case of CBV $811 \mathrm{C}$ However, the system "H-BEA-150-20 M LiCl solution" displays a spring behavior with an intrusion pressure of $59 \mathrm{MPa}$ (Fig. 2) which is not the case for the CBV 811C sample, where the intrusion of the $20 \mathrm{M} \mathrm{LiCl}$ solution occurs at atmospheric pressure, revealing thus, despites a higher $\mathrm{Si} / \mathrm{Al}$ molar ratio more hydrophilic defect sites in this sample. It is worthy to note that the intruded volume is quite low $(0.09 \mathrm{~mL} / \mathrm{g})$ and about half of the one determined from $\mathrm{N}_{2}$ adsorption-desorption experiment $(0.20 \mathrm{~mL} / \mathrm{g})$. This might indicates, as already seen for FAU-type zeolites, that a part of the pore volume is filled at atmospheric pressure.

A strong difference can be observed in the water and $20 \mathrm{M} \mathrm{LiCl}$ solution intrusion-extrusion curves of the H-BEA-150 sample ( $\mathrm{Si}$ / Al ratio of 90) with those of a pure silica "BEA-type zeol ite [26]. The corresponding curves are reported in Fig. 2. Pure silica "BEA zeolite (zeosil) shows a bumper behavior under intrusion of water and LiC solutions up to the concentration of $10 \mathrm{M}$ with an intrusion pressure of $53 \mathrm{MPa}$, whereas H-BEA-150 sample is hydrophilic under these conditions and intrusion occurs at atmospheric pressure. With the $20 \mathrm{M}$ Lid solution, both samples demonstrate a similar behavior (spring for H-BEA-150 and shock-absorber with a narrow

Table 2

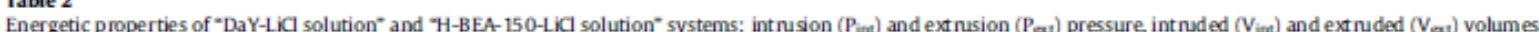
absorbed (Ea) and restored (Er) energies and energy yield (Er/Ea" 1000s).

\begin{tabular}{|c|c|c|c|c|c|c|c|c|}
\hline Sample & $\mathrm{P}_{\text {im }} \mathrm{MPa}$ & $\mathrm{P}_{\mathrm{eat}} \mathrm{MPa}$ & $\mathrm{v}_{\mathrm{m}} \mathrm{mL} / \mathrm{g}$ & $\mathrm{v}_{\mathrm{eat}} \mathrm{mL} / \mathrm{g}$ & $E_{A} \mathrm{~J} / \mathrm{g}$ & $\mathrm{E}_{f} \mathrm{~J} / \mathrm{g}$ & Yield $x$ & Behavior \\
\hline DaY-10 M Lid & 14.5 & 7 & 0.17 & 0.17 & 2.5 & 1.2 & 48 & Shock-absorber \\
\hline DaY-15 M Lid & 25.5 & 13.5 & 0.23 & 0.23 & 5.9 & 3.1 & 51 & Shock-absorber \\
\hline H-BEA-150-20 M LiC & 59 & 57 & 0.09 & 0.09 & 5.3 & 5.1 & 97 & Spring \\
\hline
\end{tabular}


hysteresis for "BEA zeosil), but the intrusion pressure and the intrusion volume in the H-BEA- 150 sample are considerably lower than the ones in "BEA zeosil (59 MPa, $0.09 \mathrm{~mL} / \mathrm{g}$ and $115 \mathrm{MPa}$, $0.16 \mathrm{~mL} / \mathrm{g}$, respectively). Thus we can conclude that the presence of a small amount of aluminum in the zeolite framework increases the hydrophilic character of the material and leads to a considerable change in the intrusion-extrusion behavior.

In the case of "BEA-type zeosil the difference between the system behavior under intrusion of low and highly concentrated LiCl solutions was explained by a change of the intruded liquid. At low LiCl concentrations, only water molecules are intruded into the pores, whereas at high $\mathrm{LiCl}$ concentrations there are no free water molecules and solvated $\mathrm{Li}^{+}$and $\mathrm{Cl}^{-}$ions are intruded [26]. In the case of $\mathrm{H}-\mathrm{BEA}$ and DaY samples we also observe a change of the system behavior with the electrolyte concentration. The zeolites demonstrate hydrophilic properties under intrusion of water (for both zeolites) and low concentrated ( $<15 \mathrm{M})$ Lid solutions (for HBEA only). However they display a shock-absorber behavior in the case of $\mathrm{DaY}$ for all Lid solutions and a spring behavior for the H-BEA sample with $20 \mathrm{M}$ Lid solution. A similar phenomenon was observed by Qiao and coworkers for "high-silica faujasite - NaCl, $\mathrm{NaBr}$ and $\mathrm{KCl}$ solution" systems [23-25]. A threshold concentration exists in all cases. However, it is difficult to determine the nature of the intruded liquid in the case of DaY zeolite, since it demonstrates a shock-absorber behavior even in the case of a $5 \mathrm{M} \mathrm{LiCl}$ solution which is characterized by a high amount of free water molecules. Generally, the increase of the intrusion pressure with the LiCl concentration can be related to a higher solid-liquid interfacial tension and/or the ions desolvation phenomenon [20,24], and at high LiCl concentration, the change of intruded liquid is also possible [26]. The change of intruded liquid can be an explanation for the increase of the intruded volume in DaY zeolite with a rise of $\mathrm{LiCl}$ concentration. Solvated $\mathrm{L}^{+}$and $\mathrm{Cl}^{-}$species of the nonwetting liquid fill the pore volume only at high pressure; the latter being close to $0.23 \mathrm{~mL} / \mathrm{g}$. Whereas, at low Lid concentration free water molecules already fill in a part of the pore volume at atmospheric pressure; consequently, the intruded volume of nonwetting solution in high pressure range is lower (about $0.13 \mathrm{~mL} / \mathrm{g}$ ).

Since only DaY and H-BEA- 150 zeolites demonstrate interesting energetic performances under intrusion-extrusion of $\mathrm{LiCl}$ solution, only their characterization by structural and physicochemical methods is presented below.

\subsection{XRD and SEM characterization}

The XRD patterns of DaY and H-BEA-150 zeolites before and after intrusion-extrusion of $20 \mathrm{M} \mathrm{LiCl}$ aqueous solution are shown in Fig 3. The XRD patterns of the H-BEA-150 samples show a sequence of large and narrow diffraction peaks typical for the "BEA zeolite which is a disordered structure. They were indexed in the tetragonal symmetry (polymorph A) and the corresponding unitcell parameters are reported in Table 3. No significant change of the unit-cell parameters (cubic symmetry) is observed after intrusion-extrusion experiments in the case of DaY sample, which means that at the long-range order, the FAU structure is not affected. In the case of H-BEA-150 sample a slight shift of the XRD peaks to lower angle values is observed after intrusion-extrusion experiments leading to an expansion of the crystal line lattice. An increase of the unit-cell volume (from 4010 to $4039 \AA^{3}$ ) is observed after $20 \mathrm{M} \mathrm{LiCl}$ intrusion-extrusion experiments. The lattice expansion is also observed after intrusion of water (XRD pattern not reported). Therefore, the slight lattice change is probably caused by the high pressure treatment and the creation of additional hydrophilic defect sites which stick water molecules after rehydration. It should be noticed that a contraction of the

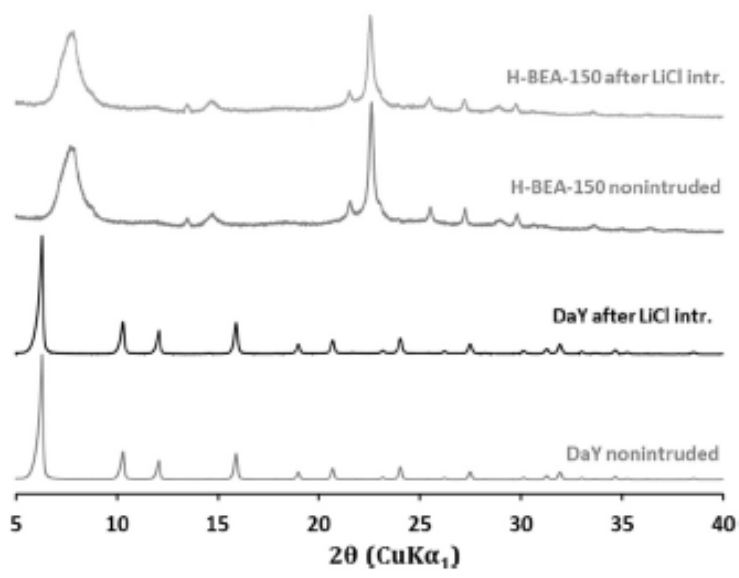

Hig. 3. X-ray diffraction pattems of the H-BEA-150 and DaY samples before and afte three intrusion-extrusion cycles in $20 \mathrm{M} \mathrm{LCCl}$ aqueous solution.

Table 3

Unit-cell parameters of H-BEA-150 (polymorph A) and DaY samp les before and after three intrusion-extrusion cycles in $20 \mathrm{M} \mathrm{LiCl}$ aqueous solution.

\begin{tabular}{llll}
\hline Sample & $\mathrm{a}(\boldsymbol{A})$ & $\mathrm{c}(\mathrm{A})$ & $\mathrm{V}\left(\mathrm{A}^{3}\right)$ \\
\hline H-BEA-150 & $12.395(8)$ & $26.189(19)$ & $4009.8(30)$ \\
H-BEA-150 -20 M LiC & $12.411(9)$ & $26.221(23)$ & $4038.7(43)$ \\
DaY & $24.272(20)$ & - & $14,300.4(20)$ \\
DaY-20 M LiC & $24.269(23)$ & - & $14,296.5(24)$ \\
\hline
\end{tabular}

crystalline lattice was observed in the case of water and $20 \mathrm{M} \mathrm{LiC}$ intrusion-extrusion experiment with pure silica 'BEA zeolite [26].

The crystal morphology of the H-BEA-150 and DaY samples was examined by scanning electron microscopy. No difference between non-intruded and water-intruded samples was found. SEM images are presented in Fig. 4. For the H-BEA sample, agglomerates with a size ranging from 150 to $300 \mathrm{~nm}$, composed from grains with a size of several tens $\mathrm{nm}$, are observed (Fig. 4A and B). The DaY sample is composed from large agglomerates of crystals with irregular shape and a size ranging from several tens to several hundreds $\mathrm{nm}$. (Fig. 4C and D).

\subsection{Thermal analysis and $N_{2}$ adsorption-desorption isotherms}

The experimental results issued from the thermogravimetric TG) analysis of H-BEA-150 and DaY samples before and afte intrusion-extrusion experiments are shown in Fig. 5. The total weight loss of H-BEA-150 sample before and after intrusion/ extrusion of $20 \mathrm{M} \mathrm{LiCl}$ solution is high -13.2 and 14.9 wt.\%, respectively. Thus, the zeolite demonstrates its hydrophilic character. Two steps are clearly observed. The first one between $30^{\circ}$ and $200{ }^{\circ} \mathrm{C}$ ( 11.1 and 12.3 wt.\%, respectively) is ascribed to the desorption of physisorbed water molecules. The second step, located between $260^{\circ}$ and $700{ }^{\circ} \mathrm{C}$, can be attributed to the removal of water molecules arising from dehydroxylation reactions. The weight loss is close to 2.1 wt.\% and 2.6 wt.\% for the nonintruded and intruded-extruded H-BEA-150 samples, respectively, that corresponds to about 9 and $11 \mathrm{OH}$-group per unit-cell. Thus, the intrusion of $20 \mathrm{M} \mathrm{LiCl}$ solution leads to a weak increase of silanol defects in the zeolite, which is in agreement with the XRD result (see above).

The thermogravimetric curves of the DaY sample show its higher hydrophobicity. Two badly pronounced steps can be 

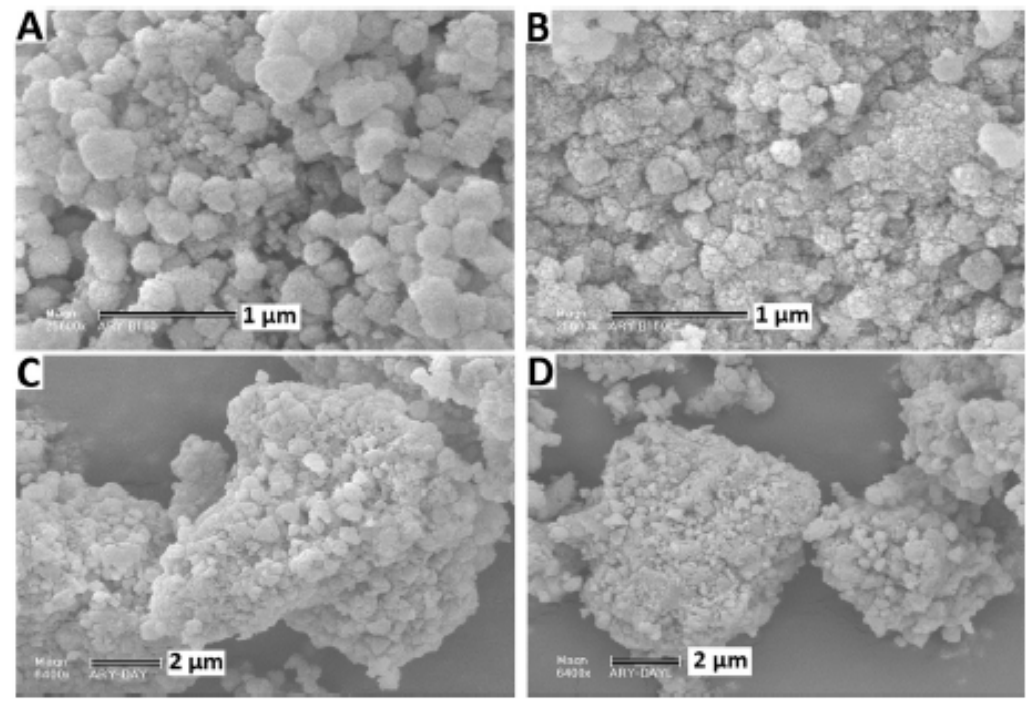

Fig. 4. SEM micrographs of the H-BEA-150 and DaY samples before (A and C, respectively) and after (B and D) intrusion-extrusion experiments

distingui shed. The first one ranging from $30^{\circ}$ to $150^{\circ} \mathrm{C}$ is ascribed to the desorption of physisorbed water molecules. The weight loss is slightly higher in the case of the nonintruded sample ( $2.2 \mathrm{wt} . \%$ against $1.7 \mathrm{wt}$.\%). This loss is followed by a continuous weight loss up to $800^{\circ} \mathrm{C}$ without clear step, probably ascribed to the removal of water molecules adsorbed on silanol groups and to the removal of water molecules arising from dehydroxylation reactions. In both cases, the values of weight loss are very close (1.2 wt.\%). Thus no additional defects seem to be formed in the DaY zeolite after the $20 \mathrm{M} \mathrm{LiCl}$ intrusion-extrusion experiment.

The $\mathrm{N}_{2}$ adsorption-desorption isotherms of the nonintruded and intruded $\mathrm{DaY}$ and $\mathrm{H}$-BEA-150 samples are shown in Fig. 6 . The isotherms are mainly of type I characteristic of microporous solids for DaY sample and of type I + type IIb for H-BEA-150. The BET surface area and microporous volume of the nonintruded $\mathrm{H}-\mathrm{BEA}$ 150 sample is equal to $535 \mathrm{~m}^{2} / \mathrm{g}$ and $0.20 \mathrm{~cm}^{3} / \mathrm{g}$. For the intruded-extruded sample with $20 \mathrm{M} \mathrm{LiCl}$ solution the surface area and pore volume are slightly lower: $\mathrm{S}_{\mathrm{BET}}=492 \mathrm{~m}^{2} \mathrm{~g}^{-1}$ and

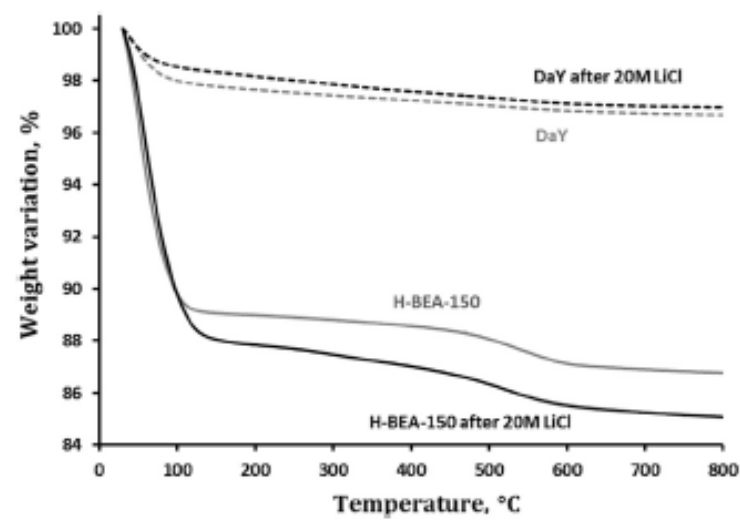

Fig 5. Th curves of the H-BEA-150 and DaY samples before and after three intrusion-extrusion cycles in $20 \mathrm{M}$ LCl solution.
$\mathrm{V}_{\text {micro }}=0.18 \mathrm{~cm}^{3} \mathrm{~g}^{-1}$. Such a result is quite surprising since defect sites after intrusion -extrusion experiment are expected from the TG analysis. In the case of DaY zeolite the BET surface area and microporous volume values before and after intrusion-extrusion are very close: $821 \mathrm{~m}^{2} / \mathrm{g}$ and $0.30 \mathrm{~cm}^{3} / \mathrm{g}$ and $804 \mathrm{~m}^{2} / \mathrm{g}$ and $0.29 \mathrm{~cm}^{3} / \mathrm{g}$ for the nonintruded and the $20 \mathrm{M} \mathrm{LiCl}$ solution intruded samples, respectively, which is in agreement with the TG analysis.

\section{4. ${ }^{29}$ Si MAS NMR spectroscopy}

The ${ }^{29} \mathrm{Si}$ MAS NMR spectra of the DaY and H-BEA- 150 zeolites before and after $20 \mathrm{M} \mathrm{LiCl}$ solution intrusion-extrusion experiments are shown in Fig. 7. The spectrum of the DaY zeolite exhibits a unique resonance signal located at $-108 \mathrm{ppm}$ which corresponds to $\mathrm{Q}_{4}$ groups $\left(\mathrm{Si}(-\mathrm{OSi})_{4}\right)$ associated to the one crystallographic silicon site in FAU-type structure. After $20 \mathrm{M} \mathrm{LiCl}$

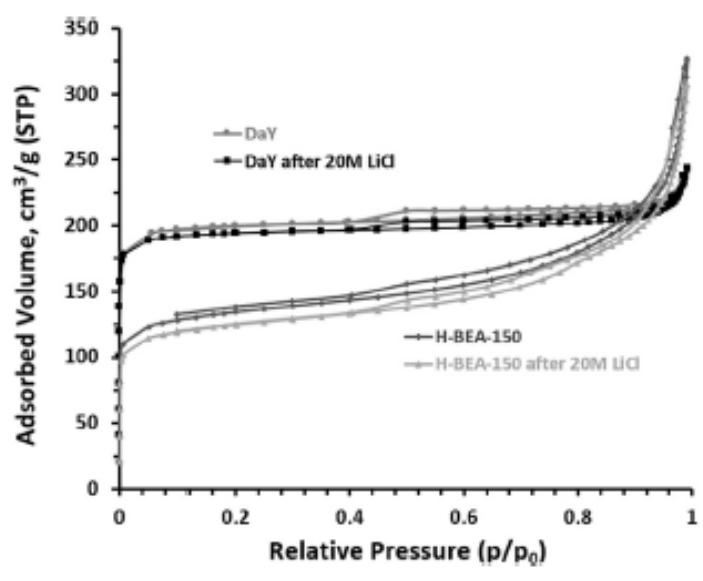

Fig. $6 \mathrm{~N} \mathrm{~N}_{2}$ adsorption-desorption isothems at $-196{ }^{\circ} \mathrm{C}$ of the DaY and $\mathrm{H}-\mathrm{BEA}-15$ samples before and after three intrusion-extrusion cydes in $20 \mathrm{M}$ LCl solution. 


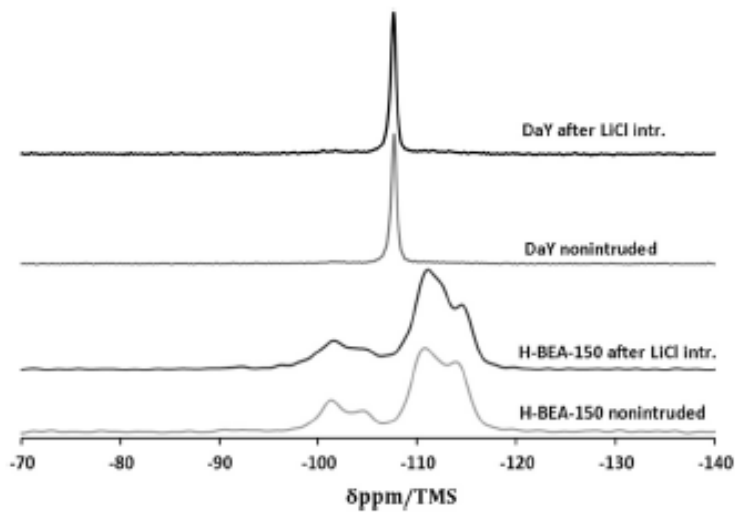

Fig 7. ${ }^{29} \mathrm{Si}-\mathrm{MAS}$ NMR spectra of DaY and H-BEA-150 zeolites before and after three intrusion-extrusion cycles in $20 \mathrm{M} \mathrm{LiCl}$ aqueous solution.

intrusion-extrusion experiments no significant change of the spectrum is observed. The spectrum of H-BEA- 150 sample exhibits two main broad resonances with maxima at -111 and $-114 \mathrm{ppm}$ ascribed to the non equivalent crystallographic $Q_{4}$ silicon sites and two broad resonances at -101.5 and $-105 \mathrm{ppm}$ corresponding to $\mathrm{Q}_{3}$ sites ( silanol $\left(\mathrm{Si}-(\mathrm{OSi})_{3} \mathrm{OH}\right)$ groups or $\left(\mathrm{Si}-(\mathrm{OSi})_{3} \mathrm{O}^{-}\right)$groups). After intrusion-extrusion experiments a decrease of the resonance at $-114 \mathrm{ppm}$ and the broadening of $\mathrm{Q}_{3}$ components is observed. The $\mathrm{Q}_{3} / \mathrm{Q}_{4}$ area ratios determined from these spectra are equal to 0.41 and 0.39 for the intruded and nonintruded samples, respectively. revealing thus the creation of defect sites (about $5 \%$ ) after $20 \mathrm{M} \mathrm{LiCl}$ intrusion-extrusion experiment.

\section{5. ${ }^{1} \mathrm{H}-{ }^{29} \mathrm{Si}$ CPMAS NMR spectroscopy}

The ${ }^{1} \mathrm{H}-{ }^{29} \mathrm{Si}$ CPMAS NMR spectra of the DaY and H-BEA-150 samples before and after $20 \mathrm{M} \mathrm{LiCl}$ solution intrusion-extrusion are reported in Fig. 8. These spectra were performed to enhance the silicon atoms that bear protons and thus to get evidence of the presence of silanol groups. The ${ }^{1} \mathrm{H}-{ }^{29} \mathrm{Si}$ CPMAS technique does not provide quantitative results; however, it allows a relative comparison of the spectra if they were registered under the same conditions. On the spectrum of the nonintruded DaY zeolite, a very broad

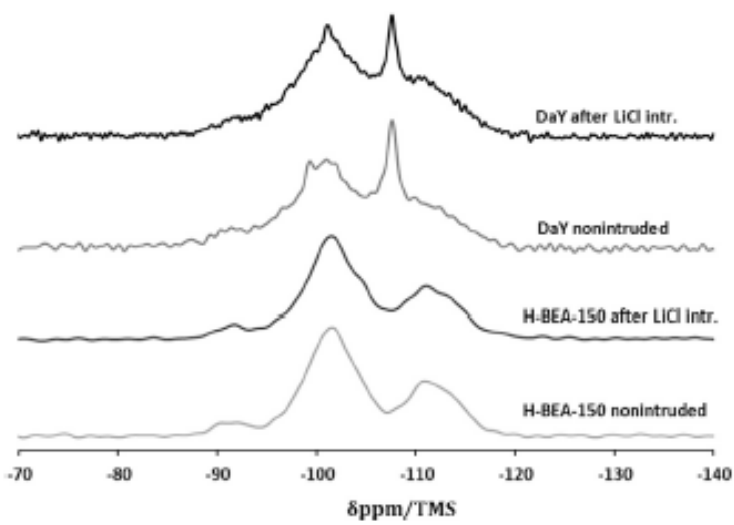

Fig 8. ${ }^{1} \mathrm{H}-2 \mathrm{Si}$ CPMAS NMR spectra of DaY and $\mathrm{H}-\mathrm{BEA}-150$ zeolites before and after three intrusion-extrusion cycles in $20 \mathrm{M} \mathrm{LiCl}$ aqueous solution. signal is observed in the $\mathrm{Q}_{4}$ range with a well pronounced resonance at $-108 \mathrm{ppm}$, a broader one in the $Q_{3}$ range and very small broad resonance in the $\mathrm{O}_{2}$ range. After intrusion of $20 \mathrm{M} \mathrm{LiCl}$ solution no considerable change is observed, only the resonance of $\mathrm{Q}_{3}$ groups at - $101 \mathrm{ppm}$ becomes more pronounced.

On the spectrum of H-BEA-150 zeolite three broad resonances at $-92,-102$ and $-112 \mathrm{ppm}$ are observed. The first one of weak intensity is ascribed to $\mathrm{Q}_{2}$ groups $\left(\mathrm{Si}(-\mathrm{OSi})_{2}(-\mathrm{OH})_{2}\right)$. The other resonances correspond to the $\mathrm{Q}_{3}$ and $\mathrm{Q}_{4}$ groups, respectively. Although a slight increase of defect sites (about 5\%) was evidenced by ${ }^{29} \mathrm{Si}$ MAS NMR after intrusion-extrusion of $20 \mathrm{M} \mathrm{LiCl}$ solution (see above), no significant change is observed on the CP MAS NMR spectra of the H-BEA-150 samples.

\section{Conclusions}

A study of energetic performances of several FAU-type and "BEA-type zeolites with different Si/Al molar ratio has been performed by high pressure intrusion-extrusion of water and $\mathrm{LiCl}$ aqueous solutions. It has been shown that most of FAU-type zeolites demonstrate hydrophilic properties and spontaneous intrusion of water and LiCl solutions. Only high-silica Y zeolite (DaY sample) with a Si/Al ratio of 110 displays a shock-absorber behavior under intrusion of $\mathrm{LiCl}$ solutions. The increase of the $\mathrm{LCCl}$ concen tration leads to a rise of the intrusion pressure from 8.5 to $34 \mathrm{MPa}$ for $5 \mathrm{M}$ and $20 \mathrm{M} \mathrm{LiCl}$ solutions, respectively. An increase of the intruded volume was also observed - from 0.13 to $0.23 \mathrm{~mL} / \mathrm{g}$. It can be related with a change of the intruded liquid from water to solvated $\mathrm{Li}^{+}$and $\mathrm{Cl}^{-}$ions in the case of highly concentrated solutions. The latter nonwetting liquid fill the pore volume at high pressure, whereas at low LiCl concentration a part of the pore volume is al ready filled spontaneously at atmospheric pressure by free water molecules.

"BEA zeolite characterized by a Si/Al molar ratio of 90 displayed a spring behavior under intrusion of $20 \mathrm{M} \mathrm{LiCl}$ solution with an intrusion pressure of $59 \mathrm{MPa}$ and an intruded volume of $0.09 \mathrm{~mL} / \mathrm{g}$, whereas at lower $\mathrm{LiCl}$ concentrations the intrusion is spontaneous. In the same conditions pure-silica "BEA zeolite shows a shockabsorber behavior with an intrusion pressure of $115 \mathrm{MPa}$ and an intruded volume of $0.16 \mathrm{~mL} / \mathrm{g}$ and a bumper behavior under intrusion of water and $\mathrm{LiCl}$ solutions up to the concentration of $10 \mathrm{M}$. Thus, the presence of small traces of aluminum atoms changes considerably the behavior of the "'BEA-type zeolite - solution" system.

\section{Acknowledgments}

The authors would like to thank Dr. S. Rigolet for fruitfu discussions.

\section{References}

[1] J. Cejka, H. Van Bekkum, A. Corma, F. SchQth, Stud. Surf. Sci. Catal. 168 (2007) $525-544$

[2] V. Eroshenko, R.C Regis, M. Soulard, J. Patarin, J. Am. Chem. SoC. 123 (2001) $8129-8130$.

[3] M. Soulard, J. Patarin, V. Eroshenko, R. Regis, Stud. Surf. Sci. Catal. 154B (2004) $1830-1837$.

4] V. Eroshenko, RC. Regis, M. Soulard, J. Patarin, C R. Phys 3 (2002) 111-119 5] N. Desbiens, L. Demachy, A. Fuchs, H. Kirsh-Rodeschini, M. Soulard, J. Patarin Angew. Chem. Int. Ed, 44 (2005) 5310-5313.

6] M. Trzpit, M. Soulard, f. Patarin, Chem. Lett 36 (2007) 980-981.

[7] M. Trzpit, M. Soulard, J. Patarin, N. Desbiens, F. Cailliez, A. Boutin, L. Demachy. A. Fuchs, Langmuir 23 (2007) 10131-10139.

[8] F. Cailliez, M. Trzpit, M. Soulard, 1. Demachy, A. Boutin, f. Patarin, A. Fuchs, Phys, Chem. Chem. Phys. 10 (2008) 4817-4826.

9] M. Trzpit, S. Rigolet, J.-L. Paillaud, C Marichal, M. Soulard, J. Patarin, J. Phys. Chem. B 112 (2008) $7257-7266$. 
[10] M.-A. Saada, S. Rigolet, J-L. Paillaud, N. Bats, M. Soulard, J. Patarin, J. Phys. Chem. C 114 (2010) $11650-11658$

[11] M.-A. Saada, M. Soulard, B. Marler, H. Gies, J. Patarin, J. Phys, Chem. C 115 (2011) $425-430$. [12] L Tzanis, M. Trzpit, M. Soulard, J. Patarin, Microporous Mesoporous Mater 146
(2011) 119-126.

[13] L. Tzanis, M. Trzpit, M. Soulard, J. Patarin, J. Phys, Chem. C 116 (2012) 14] L. Tzanis, B. Marler, H. Gies, M. Soulard, J. Patarin, J. Phys, Chem. C 117 (2013) 4098-4103.

[15] 1. Khay, L. Tzanis, T.J. Daou, H. Nouali, A. Ryzhikov, J. Patarin, Phys Chem. Chem. Phys. 15 (2013) 20320-20325.

[16] A. Ryzhikov, 1. Khay, H. Nouali, T.J. Daou, f. Patarin, RSC Adv, 4 (2014) 37655-37661.

[17] O.V. levtushenko, V.A. Eroshenko, Ya G. Grosu, J-M. Nedelec, J-P.E. Grolier, Phys. Chem. Chem. Phys. 15 (2013) 4451-4457.

[18] T. Karbowiak, M.-A. Saada S. Rigolet, A Ballandras G. Weber, L. Bezverkhyy. M. Soulard, J. Patarin, J.-P. Bellat, Phys. Chem. Chem. Phys, 12 (2010) M. Soulard,
[19] L. Tzanis, M. Trzpit, M. Soulard, J. Patarin, J. Phys, Chem. C 116 (2012) $20389-20395$.

20] L. Tzanis H. Nouali, T.J. Daou, M. Soulard, J. Patarin, Mater, Lett. 115 (2014) 229-232

21] A. Han, Y. Oiao, J. Mater. Res, 22 (2007) 644-648.

22] L. Khay. T. Daou, H. Nouali, A. Ryzhikov, S. Rigolet, J. Patarin, J. Phys, Chem. C 18 (2014) 3935-3941.

[23] A. Han, Y. Qiao, Appl. Phys, Lett. 91 (2007) 173123-173127.

[24] A. Han, W. Lu, T. Kim, X. Chen, Y. Qiao, Phys. Rev, E 78 (2008) $031408-0314112$

[25] A. Han, W. Lu, T, Kim, Y.K. Punyamurtula, Y. Qiao, Smart. Mater. Struct. 18 (2009) 024005-024010.

[26] A. Ryzhilov, 1. Khay, H. Nouali, T. D aou, J. Patarin, Phys. Chem. Chem. Phys. 16 (2014) 17893-17899.

[27] T. Chatelain, J. Patarin, M. Soulard, P. Schulz, JL. Guth, Zeolites 15 (1995) $90-96$

28] A. Boultif, D. Louër, L Appl, Crystallogr. 24 (1991) 987-993.

[29] STOE WinXPOW, Version 1.06, STOE and Cie, Damstadt, Germany, 1999. 